\title{
Do Medical Students Experience Writing Anxiety While Learning English as a Foreign Language?
}

This article was published in the following Dove Press journal:

Psychology Research and Behavior Management

\author{
Reem I Rabadi $\mathbb{I}^{\prime}$ \\ Alexander D Rabadi ${ }^{2}$ \\ 'School of Applied Humanities and \\ Languages, German Jordanian University, \\ Amman, Jordan; ${ }^{2}$ School of Medicine, \\ University of Jordan, Amman, Jordan
}

\begin{abstract}
Aim: The study examines English Foreign Language (EFL) writing anxiety among medical students in terms of the levels, types, and causes of writing anxiety.

Methods: This study is a cross-sectional study consisting of 684 first-year medical students from Jordanian universities. The participants responded to an online survey consists of Second Language Writing Anxiety Inventory (SLWAI) and Causes of Writing Anxiety Inventory (CWAI), 15 of whom were invited for semi-structured interviews.

Results: The results reveal that the participants experience a high level of writing anxiety, with cognitive anxiety as its dominant type. As for the main causes of writing anxiety, they are linguistic difficulties, insufficient writing practice, low self-confidence in writing, and fear of writing tests. The findings from qualitative data obtained from semi-structured interviews reinforce the results of quantitative data.

Conclusion: The study sheds light on the problems of English Foreign Language writing anxiety and raises awareness of language teachers and syllabus designers.
\end{abstract}

Keywords: foreign language anxiety, writing anxiety, medical students, language learning

\section{Introduction}

Learners of English as a foreign or second language confront various difficulties due to different factors, they are learners, teachers, and language factors. ${ }^{1}$ Anxiety is one of the psychological aspects of the learners factors, which prevents them from developing their skills when learning English as a foreign or second language. ${ }^{2,3}$ Second language anxiety is defined as the feeling of tension and apprehension specially associated with second language contexts, including speaking, listening, and writing. ${ }^{4}{ }^{(284)}$ As for foreign language learning anxiety, it implies concern and agitation about learning a new language. ${ }^{5}$ Foreign Language Anxiety (FLA) proposed by Horwitz, Horwitz, and Cope as self-conceptions, attitudes, feelings, and behaviors connected to language learning in the class that occur from the exclusivity of the process of language learning. ${ }^{6}(128)$

English as a Foreign language (EFL) anxiety negatively affects the learning process of EFL learners, ${ }^{7,8}$ as they become less engaged in language learning. ${ }^{9}$ It also causes them to face difficulties understanding teaching material and even avoiding attending writing classes. ${ }^{10}$ Possibly, this may hinder the progress of the learners' competence, such as writing, ${ }^{11}$ and it may perhaps influence their performance. ${ }^{8}$

It is irrefutable that writing is a challenging skill for EFL learners as it is a hard task to master, ${ }^{10,12}$ or it is a complicated skill compared with the other three skills. ${ }^{13}$ Other challenges that EFL learners usually face when performing writing are the
Correspondence: Reem I Rabadi

School of Applied Humanities and Languages, German Jordanian University, P. O. Box: 926 594, Amman II 190, Jordan Tel +962-797220I55

Email reem.rabadi@gju.edu.jo
Psychology Research and Behavior Management 2020:13 883-893 
lack of the right lexical items and grammatical rules for EFL beginners; advanced learners struggle with coherency and language discourse. ${ }^{14}$ These challenges are factors provoking writing anxiety among EFL learners. Many studies in the field of EFL writing instruction have emphasized that writing anxiety is a vital aspect that affects the quality in addition to the perception of writing among EFL learners. One of the effects of the writing anxiety on EFL learners is the negative attitudes towards writing and low motivation that cause them to obtain low results. ${ }^{15}$ As a result of writing anxiety, EFL learners are discouraged from expressing their ideas, and they are unable to manage their writing self-efficacy, ${ }^{16}$ besides they become more intense, anxious, and feel insecure while writing. ${ }^{15}$ Therefore, as a consequence of all these effects of writing anxiety, the writing performance of EFL learners is influenced negatively, ${ }^{17}$ also, they may suffer from high levels of anxiety while learning a language. ${ }^{18}$ As for the causes of writing anxiety, they are poor linguistic skills, time stress, fear of negative feedback, and students restrain themselves to progress in writing. ${ }^{19}$

Regarding Arabic EFL learners, they encounter problems acquiring the fundamental language skills of English, notably writing. ${ }^{20}$ Jordanian EFL learners, who are part of the EFL Arab context, confront this problem too. $^{21-23}$ Several studies in the Jordanian EFL context verify that EFL Jordanian students face several difficulties in the four language skills, mostly in writing. ${ }^{24-27}$ Consequently, Jordanian English language educators generally resent about the weaknesses of their students and specifically about school leavers who join the universities. ${ }^{22}$ Regarding the causes of defects of the Jordanian EFL students, they are attributed to the absence of good writing technical skills, deficiency of enough linguistic knowledge, the limited number of lexical items, and anxiety that is aroused when they are obliged to write. ${ }^{29-32}$ These weaknesses apply to medical students in Jordan, as they are part of the Jordanian EFL context, and they are school leavers who joined universities to study medicine. Thus, their English language problems are the same as the rest of other EFL Jordanian students.

Studies on EFL or English as a second language (ESL) writing indicated that writing anxiety could have significant effects on EFL/ESL writing performance. ${ }^{32-34}$ Numerous researchers use the term "writing apprehension" instead of writing anxiety as writing apprehension has been considered as synonymous with writing anxiety. ${ }^{35-39}$ The researchers of the present study found very few numbers of studies that have paid attention to the situation of writing apprehension among EFL Jordanian learners as a study by Huwari and Abd Aziz, ${ }^{40}$ two studies conducted by Al Sawalha and Foo, ${ }^{18,41}$ and research by Haddad. ${ }^{42}$

In line with the review of related studies and lack of literature on EFL writing anxiety within the Jordanian educational setting. This study investigates the levels, types, and causes of writing anxiety among EFL medical students in Jordan.

\section{Literature Review Overview of Foreign Language Anxiety}

Foreign language anxiety is a situation-specific type of anxiety related to the language learning context, which differs from personal trait-related anxiety. ${ }^{33}$ Following this approach, the results of research on FLA have been relatively uniform. ${ }^{43}$ According to Brown, anxiety which can be a debilitative or facilitative factor plays a role in second or foreign language learning. ${ }^{1}$ Debilitative anxiety is the negative kind that affects the performance of learners to some extent; several studies have revealed the negative linear relationship between learners' anxiety and their performance in language classes. ${ }^{44}$ On the other hand, the positive aspect of anxiety is the facilitative anxiety that is helpful to some degree. ${ }^{45-47}$ Spielmann and Radnofsky declared that sometimes anxiety is good for learning even though some learners cannot stand learning a language under stress. ${ }^{48}$

Reviewing the literature concerning the effect of FLA on the performance or achievement of foreign language learners, a plethora of research has found a negative relationship between FLA and FL performance in a large number of contexts and situations. ${ }^{49-51}$ In a study of English learners of Spanish or French, Horwitz showed that anxiety negatively affected the final exam grades of learners of Spanish and French. ${ }^{49}$ In another study, Frantzen and Magnan measured the FLA anxiety of 490 students enrolled in first-semester French and Spanish at the University of Wisconsin Madison. ${ }^{52}$ They were classified as true beginners, who had no previous study of the language, and false beginners, who studied the language in high school or college, regardless of the number of years. The findings indicated that true beginners were significantly more anxious than false beginners and received lower grades than false beginners. ${ }^{52}$ Also, Shahnaz and Bhatti's study investigated the relationship between English language anxiety, English language interest, and 
English language achievement of 97 undergraduate students of BS Computer Sciences, Telecom engineering and Computer engineering program from various cities of Pakistan. The findings revealed a significant negative correlation between English language anxiety and English language achievement and between English language anxiety and English language interest. This implies that students who experienced a high level of English language anxiety performed poorly in the English language achievement. $^{53}$

Likewise, numerous studies have examined the relationship between FLA and specific language skills ie speaking, listening, reading, and writing skills. ${ }^{54-56}$ Park and Lee found a significant negative correlation between the anxiety of 132 Korean L2 college students and their speaking skills. More anxious students obtained lower scores on their oral performance. ${ }^{57}$ As for listening, Golchi revealed a negative correlation between listening anxiety of 63 Iranian IELTS learners and listening comprehension, those who were less anxious did better on the listening comprehension test. ${ }^{58}$ Regarding writing, the research of Huerta et al was derived from a qualitative analysis of 174 graduate students in an American university who attended a writing class and an out-of-class workshop. ${ }^{59}$ The findings indicated that their anxiety correlated negatively with their confidence in regulating their writing. ${ }^{59}$ Finally, Sellers inspected the relationship between language anxiety and reading skills of 89 university-Spanish students. ${ }^{60}$ It was revealed that anxious students were unable to understand the assignments correctly and tend to remember less passage content while reading than their less anxious counterparts. ${ }^{60}$

In sum, foreign language anxiety does not only affect the learning process of learners, but it also has a negative relationship between foreign language anxiety and language skills.

\section{Writing Anxiety}

In terms of writing anxiety, Erkan and Sabanas has defined writing anxiety as the tendency of a person to avoid the process of writing-particularly when it is to be evaluated in some way. ${ }^{61(181)}$ As writing anxiety is a subject and situationspecific anxiety, Hassan defines it as a general avoidance of writing behavior and of situations thought to potentially require some amount of writing accompanied by the potential for evaluation of that writing. ${ }^{32(4)}$ Nevertheless, writing anxiety is identified in the current study as a situational aspect, which is concerned with feelings of stress along with reactions as excessive perspiration, palpitation, and negative impressions. In addition to the maladaptive behaviors of students while writing as a lack of confidence and writing avoidance behaviour.

Foreign language learners may be anxious when asked to write, and their anxiety can be noticed from their way of behaving, feelings, and written performance. $6,10,52$, Regarding the written work of FL anxious learners, they are subject to have difficulty in maintaining writing goals and organizing ideas, making many lexical errors, and using inappropriate grammatical rules in the composition. ${ }^{17,32,62,63}$ However, there are some common causes as adapting to a new type of writing, writing for very analytical or demanding readers, experiencing negative evaluation on their writing tasks in the past, or working with a short time. ${ }^{5,15,16,19,34}$ In the context of the impact of writing anxiety on writing ability is a controversial topic in language learning research. Some scholars believe that writing anxiety affects positively the writing ability of students as it activates their concentration and accurateness. ${ }^{1,46,47}$ Conversely, numerous studies have divulged that anxiety causes students' low writing performance. $^{17,19,64}$

Cheng proposed a concept of three dimensions of anxiety consists of Somatic anxiety, (the physiological effect), Cognitive anxiety (cognitive aspect of anxiety experience), and Avoidance behaviour (avoiding writing). ${ }^{34}$ These three types of writing anxiety stemmed from the Second Language Writing Anxiety Inventory (SLWAI), these types affect students' process of writing and their behaviors in learning a foreign language. ${ }^{34}$ Moreover, Cheng exposed that the negative relationship between test anxiety and writing performance is mainly caused by the cognitive factors rather than somatic factors or avoidance behavior. ${ }^{34}$

Writing anxiety among EFL learners has been inspected by numerous scholars, the studies are mainly about the levels, types, and factors of anxiety. Most of the studies have concluded a negative linear relationship between EFL learners' writing anxiety and their performance on writing tasks. Following this line, recent research on EFL learners' writing anxiety in different contexts will be demonstrated in this section.

In the Iranian context, Jebreil et al studied the level of writing anxiety among 45 Iranian EFL students with different proficiency levels (elementary, intermediate, and advanced learners). They were selected randomly from among students at Azad University in Iran. To collect data, Second Language Writing Anxiety Inventory (SLWAI) by (Cheng, 2004) was used. The findings of the 
study indicated that Iranian EFL students experienced a high level of anxiety. Furthermore, participants of the elementary level suffered a higher level of EFL writing anxiety than participants of intermediate and advanced levels. In terms of anxiety type, findings showed that the most common type among the students was cognitive anxiety, followed by somatic anxiety, and avoidance behavior. It was concluded that teachers have to be careful about the negative effect of anxiety on students' language learning and performance, and they should provide effective feedback to improve students' self-confidence. ${ }^{51}$

Regarding a study of higher education EFL learners in a Turkish context, Kırmızı and Kırmızı examined writing self-efficacy, writing anxiety, and the causes of writing anxiety of 172 undergraduate English Language and Literature students from a Turkish state university. The Second Language Writing Anxiety Inventory (SLWAI) designed by (Cheng, 2004), and Causes of Writing Anxiety Inventory (CWAI) and Writing Efficacy Scale (WES) originated by Yavuz-Erkan (2004) were used to collect the data of the study. The results exposed that the participants experienced a moderate level of writing anxiety, and male participants suffered less writing anxiety than female participants. Concerning the causes of writing anxiety, the findings revealed that time pressure and negative evaluation of language instructors were the main causes. As a final point, correlation analysis exposed a strong negative correlation between writing selfefficacy and writing anxiety of the participants. ${ }^{15}$

On the subject of Indonesian EFL learners, Syarifudin researched the levels, types, and causes of writing anxiety among 28 students of the English Education Study Program at State Islamic University, Mataram, who enrolled in the Essay Writing course. Data were collected by using two instruments: Cheng's (2004) questionnaire, Second Language Writing Anxiety Inventory (SLWAI), and Zhang's questionnaire (2001) to find the causes of students' writing anxiety. The outcomes of the study disclosed that students experienced a high level of EFL writing anxiety and Cognitive anxiety was the dominant type of writing anxiety. Finally, the major sources of their EFL writing anxiety were linguistics difficulties, lack of topical knowledge, and insufficient writing techniques. ${ }^{65}$

In terms of Arabic context, Sabti et al examined writing anxiety, writing self-efficacy, and writing achievement motivation in the Iraqi EFL context. The study included 100 EFL Iraqi first-year university students majoring in the English language from the College of Education, College of Arts, and College of Education for Women at Baghdad University. Four instruments were utilized for data collection: Second Language Writing Anxiety Inventory (SLWAI) (Cheng, 2004), Writer Self-Perception Scale (WSPS) (Bottomley et al, 1998), Achievement Goal Questionnaire (AGQ) (Elliot \& Church, 1997), and one descriptive writing task. The findings of this study detected that Iraqi EFL undergraduate students experienced a high level of writing anxiety that could be the cause of their poor writing. It was concluded that negative evaluation by teachers and classmates might cause students to feel anxious in the class; consequently, they avoided writing tasks. Moreover, some physical symptoms as sweating, red faces, and silence were detected while students were performing writing tasks. It was suggested that teachers should take into consideration EFL writing anxiety, and they need to enhance their students' writing ability in addition to provide them with positive feedback to overcome their anxiety. ${ }^{20}$

The remaining studies to be considered are in the EFL Jordanian context of which most of these studies used "writing apprehension" instead of writing anxiety among EFL Jordanian learners as mentioned earlier. The first study was by Huwari and Abd Aziz; they measured writing apprehension in writing a thesis or dissertation of 103 Jordanian postgraduate students at Universiti Utara Malaysia (UUM). ${ }^{40}$ The Writing Apprehension Test (WAT) developed by (Daly and Miller, 1975) was the instrument used to measure writing apprehension. The results of the study disclosed the following: First, the majority of the students had a high level of writing apprehension. Second, there was a significant positive relationship between age and socio-economic status and writing apprehension. Finally, for the open-ended question, the majority of the participants suffered more anxiety in writing a thesis than writing tasks or writing journals. It was concluded that language instructors are required to be concerned with high writing apprehension of learners. Also, young writers are more anxious than older ones because they lack experience. As for the consequences of writing apprehension on students, they experienced avoiding writing and having difficulties in choosing a topic to write. $^{40}$

The second research by Al Sawalha and Foo, ${ }^{18}$ they investigated the cause of writing apprehension of 24 thirdyear BA English Language students at Yarmouk University in Jordan. Focus group interviews were the only instrument of measurement used to obtain data from 
volunteered students. They concluded that the majority of the students experienced a high level of writing apprehension. According to students, using Arabic, the mother tongue, in the writing classrooms did not help them to improve their proficiency level of English. On the contrary, this approach was considered by them as a considerable influence causing their high level of writing apprehension. ${ }^{18}$

The third research was also by Al-Sawalha and Foo; ${ }^{41}$ they investigated the effects of writing apprehension on the writing process of 60 third-year BA English Language and Literature students at Yarmouk University in Jordan. The two instruments used in the study were the Writing Apprehension Test (WAT) developed by (Daly and Miller, 1975 ) and the writing strategy questionnaire adapted from the questionnaire of Petric and Czárl (2003). The results of the analysis were that most of the participants experienced a high level of writing apprehension. Besides, the high level of writing apprehension of students affected the frequency and type of strategy use in writing. They avoided writing tasks and faced difficulties in expressing themselves while writing. The researchers suggested that teachers need to be aware of the high writing apprehension level of learners, they have to motivate students to practice English and write more in the class and use modern teaching methods. ${ }^{41}$

The last study was by Haddad; it explored the correlation between EFL writing anxiety and the grammatical complexity of the written compositions of EFL students in Jordan. ${ }^{42}$ The sample of the study was 87 freshmen and senior BA students of English Literature at Al-Balqa Applied University in Jordan. The measuring instrument was the Writing Anxiety Inventory (Kassem, 2017). The findings showed that freshmen students experienced a higher level of writing anxiety than senior students, in addition to a significant correlation between the level of writing anxiety and their written compositions. To improve the grammatical complexity of the written texts of the participants, teachers have to lessen the writing anxiety of EFL students. ${ }^{42}$

These studies affirmed that most EFL Jordanian learners experience a high level of writing anxiety. However, to the best of the researchers' knowledge, there is not any study inspecting EFL writing anxiety of medical students in Jordan.

In the research context, medicine is taught in Englishmedium universities in Jordan, so medical students are required to master their reading and writing skills in
English to fulfill program requirements at their universities. They also have to write legibly to convey health messages, complex scientific concepts, and critical clinical information that positively affect patient care. Accordingly, medical students need to focus on their written skills and a writing skills course have to be added to the curriculum which lacks such a course. Therefore, the results of the current study can be useful as a reference to reduce the issues of EFL writing anxiety among medical students. Moreover, it can also increase the awareness of teachers and curriculum designers to decide on the material which is suitable for its application to students.

This study investigates the levels, types, and causes of writing anxiety among EFL medical students in Jordan. The following research questions are addressed:

Q1. What are the levels of EFL writing anxiety among first-year medical students?

Q2. What are the types of EFL writing anxiety among first-year medical students?

Q3. What are the main causes of EFL writing anxiety for first-year medical students?

\section{Methodology \\ Research Design}

The current study utilizes a non-experimental mixedmethod research design. The study aims to explore the types, levels, and causes of writing anxiety among firstyear medical students in Jordan. The survey design presents a quantitative and qualitative description of the trends and attitudes of the sample. Convenience sampling technique was applied in this study using an online survey to collect data from the participants followed by a semistructured interview for a random few. It is a crosssectional study that included two questionnaires together that were shared on first-year medical students' Facebook groups. Qualitative data was in the form of semi-structured interviews administered to randomly selected participants.

\section{Participants}

The survey targeted a total of 4227 first-year medical students from different universities in Jordan. The total sample of 684 participants responded by completing the survey. The sample consisted of 425 (62.2\%) female and $259(37.8 \%)$ male students with a mean age of $18.4( \pm$ 1.2). Among these survey respondents, 15 participants (10 females and 5 males) were randomly chosen for semistructured interviews. 


\section{Ethics Statement}

The consent of the participants was granted before the questionnaire began. Participants submitted their consents electronically after they were informed that their participation was voluntary, and they had the right to withdraw from the study at any time. They were notified about the aim of the research and the data was only used for the research purpose, and thereby assuring the research was adherent to the Declaration of Helsinki 1989.

\section{Data Collection}

Data were collected by using two close-ended questionnaires within the same survey in addition to semistructured interviews. These questionnaires were Second Language Writing Anxiety Inventory (SLWAI) by (Cheng 2004) and Causes of Writing Anxiety Inventory (CWAI) developed by (Rezaei and Jafari 2014). ${ }^{19,34}$ Data were collected during June 2020 , as the study is a crosssectional one. The questionnaires were delivered using online Facebook groups that included all first-year medical students in Jordan. They were informed to answer SLWAI then CWAI, in addition to the demographic questionnaire. The response rate was $16.7 \%$, and only the fully answered questionnaires were taken for data purposes, thus eliminating any possible outliers.

Afterward, the semi-structured interview was assigned to 15 randomly chosen survey respondents. They were selected according to the statistical analysis on the SLWAI questionnaire, belong to the high, moderate, and low level of anxiety. The interviews were administered using the Zoom App, each of which lasted 10-15 minutes. All the interviews were checked and transcribed verbatim.

\section{Research Instruments}

The current study used two adapted questionnaires and semi-structured interviews to collect data. The first questionnaire was Second Language Writing Anxiety Inventory (SLWAI). SLWAI is a 22-item questionnaire developed by Cheng about the anxiety student writers experience when writing in English. ${ }^{32}$ It was used to gauge the medical students' attitudes, beliefs, and anxious feelings toward EFL writing. Three categories of anxiety are represented by three subscales of SLWAI: Somatic anxiety (as reflected in negative feelings such as tension and nervousness), Cognitive anxiety (as reflected in negative expectations, preoccupation with performance, worry or fear of negative evaluation), and Avoidance behaviour (as reflected in avoidance in writing).

The Second questionnaire was Causes of Writing Anxiety Inventory (CWAI) developed by Rezaei and Jafari. ${ }^{19}$ It is a 10 -item questionnaire that was developed on the basis of causes of writing anxiety ranging from fear of a teacher's negative comment to low self-confidence in writing. Both questionnaires are rated on a 5-point Likerttype scale ranging from 1(strongly agree) to 5 (strongly disagree).

Finally, a semi-structured interview was employed to attain the participants' view of EFL writing anxiety. The interviewees were asked questions as to their feelings when writing in English, situations in which they feel anxious to write in English, reasons for anxiety when writing in English.

A pilot session for the survey was conducted to 20 participants, who were not involved in the study, to verify that the participants could understand the questionnaires, and to disclose any possible problems that they could encounter. The data obtained from SLWA and CWAI were calculated with Cronbach-Alpha $(\alpha)$ value to assess the reliability coefficient of the questionnaires. The reliability of the number of SLWAI was $(\alpha=0.88)$, and CWAI was $(\alpha=0.80)$, which demonstrates that overall scales are internally consistent. Accordingly, the present questionnaires proved to be reliable, valid, and appropriate for use in this study.

Confirmatory Factor Analysis (CFA) was also conducted to measure the construct validity of SLAWI. A chisquare test and several fit indices were selected to test the fit of the model for the present dataset. The results of the CFA analysis for SLWAI were chi-square $(203, \mathrm{~N}=684)=$ 328.377, Comparative Fit Index $(\mathrm{CFI})=0.901$, Tucker Lewis index $(\mathrm{TLI})=890$, Standardized Root Mean Residuals $(\mathrm{SRMR})=0.077$, and Root Mean Squared Error of Approximation $(\mathrm{RMSEA})=0.062$. The CFA demonstrated that SLWAI had an acceptable overall model fit.

\section{Data Analysis}

The collected data in this study were analyzed using both qualitative and quantitative methods of data analysis. The collected data was transferred to the SPSS package programme version 25 from Excel document. Then the obtained data from the semi- structured interviews were analysed through content analysis and pattern coding. 
Table I Descriptive Statistics of the SLWAI

\begin{tabular}{|l|l|l|l|l|l|}
\hline Level of Writing Anxiety & N & Minimum Score & Maximum Score & $\overline{\mathbf{x}}$ & SD \\
\hline High Anxiety & 362 & 81 & 110 & $87.91 \geq 65$ \\
Moderate Anxiety & 274 & 60 & 80 & $61.9 \leq 65$ & 5.91 \\
Low Anxiety & 48 & 37 & 59 & $49.76 \leq 65$ \\
Total & 684 & & & 66.52 & 6.41 \\
\hline
\end{tabular}

\section{Findings}

\section{Levels of Writing Anxiety}

The participants' EFL writing anxiety levels were measured by the questionnaire SLWAI to answer the first research question. Consistent with Zhang's scoring system, a mean score above 65 signifies a high level, a mean score less than 50 implies a low level, and a mean score between 50 and 65 denotes a moderate level of anxiety. ${ }^{66}$ Table 1 displays the descriptive statistics of SLWAI. The mean score was $(\bar{x}=66.52, \geq 65)$, which indicates a high level of EFL writing anxiety among first-year medical students.

\section{Types of Writing Anxiety}

The descriptive statistics for the three categories of anxiety (Cognitive anxiety, Somatic anxiety, and Avoidance Behavior) of SLWAI selected by the participants were analysed to answer the second research question of the study. As shown in Table 2, Cognitive anxiety $(\bar{x}=25.13)$ was the dominant and most common type of writing anxiety among first-year medical students.

\section{Causes of Writing Anxiety}

To answer the third research question, CWAI was utilized to expose the main causes of EFL writing anxiety among the respondents. As can be noticed from Figure 1, the main causes of writing anxiety among first-year medical students were linguistic difficulties (86\%), insufficient writing practice $(83 \%)$, low self-confidence in writing $(75 \%)$, and fear of writing tests $(73 \%)$.

\section{Results of the Interview}

Semi-structured interviews were administered to 15 participants randomly chosen to provide more in-depth information about the participants' experience of EFL writing anxiety. The findings from the content analyses and pattern coding are presented in Table 3.

Among the main sources of EFL writing anxiety were poor linguistic knowledge and insufficient writing practice writing abilities as stated by high and moderate anxious groups. Some interviewees stated:

- I feel nervous while writing because I have difficulty expressing myself, I cannot find the words I need. (High anxious student)

- I always feel uncomfortable, I have always grammatical mistakes and my writing is not clear and it's difficult to read. (Moderate anxious student)

Fear of writing tests and negative evaluations by teachers were the other sources of students' writing anxiety. The following statements by high anxious students reflected these causes:

I worry a lot about getting a low grade when I write a composition.

- Sometimes I feel anxious because I have to finish my writing test on time. I do not want to be embarrassed in front of my classmates.

The interviewees reported other causes of anxiety as lack of sufficient time for writing practice and lack of interest in writing. A statement by one of the high anxious group as an example:

- Teachers do not consider the time pressure we experience as they assign us a lot of work to do, they expect us to practice writing. I do not have the time to write even if I want to write. I do not enjoy writing my essays as I feel nervous because I cannot finish writing them.

Table 2 The Mean of Each Category of Writing Anxiety

\begin{tabular}{|l|l|l|l|}
\hline Types of Writing Anxiety & N & $\overline{\mathbf{x}}$ & SD \\
\hline Cognitive & 684 & 25.13 & 5.27 \\
Somatic & 684 & 21.78 & 4.38 \\
Avoidance Behavior & 684 & 19.67 & 2.55 \\
\hline
\end{tabular}




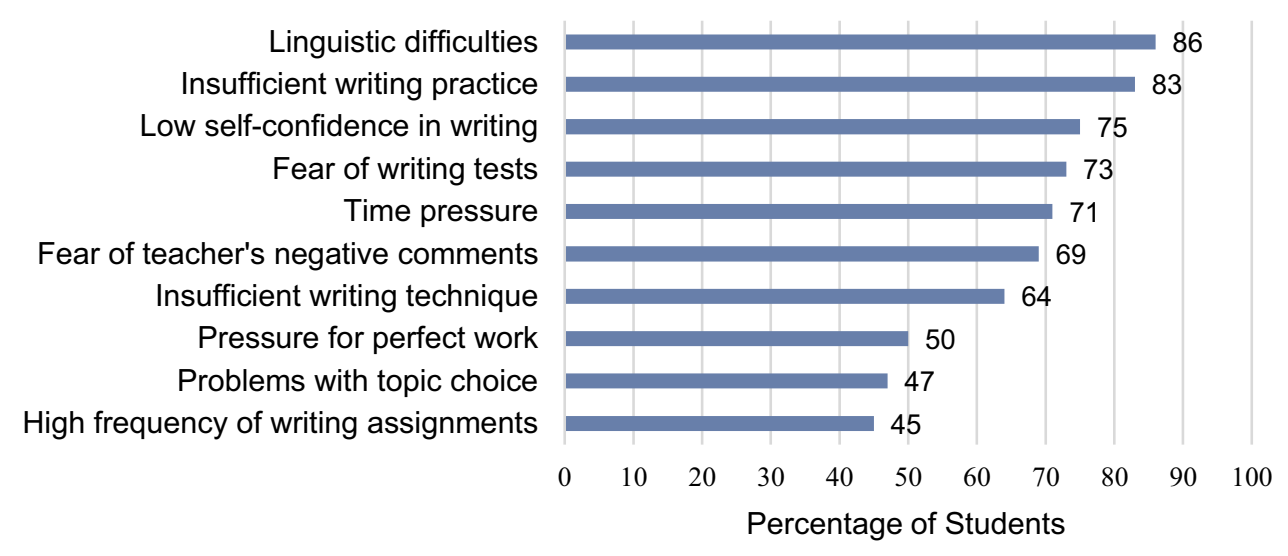

Figure I Descriptive Statistics of the Causes of Writing Anxiety Inventory.

Overall, the findings of the interview reinforced the data obtained from the CWAI.

\section{Discussion}

The main purpose of the study was to determine the levels, types, and causes of foreign language writing anxiety among first-year medical students in Jordan. The findings indicate that the participants of the study had a high level of EFL writing anxiety as the mean score of SLWAI questionnaire was $(\bar{x}=66.52, \geq 65)$. The analysis of the types of writing anxiety reveals that Cognitive anxiety with the mean score of 25.13 was the dominant type of EFL writing anxiety experienced by the participants. Furthermore, the main causes of EFL writing anxiety were linguistic difficulties (86\%), insufficient writing practice $(83 \%)$, low self-confidence in writing (75\%), and fear of writing tests $(73 \%)$.

The results of this study are in line with previous studies that revealed most of the students experienced a high level of EFL writing anxiety. ${ }^{19,67}$ The rational explanation for those same findings is that the students experience high-level writing anxiety due to the same context of English as a foreign language. Conversely, the result of the current study is not similar to the finding of Ekmekçi's study. ${ }^{5}$ The results showed that the participants experienced moderate writing anxiety as they were senior EFL students. ${ }^{5}$ It can be concluded that more experience and more proficient learners in English may decrease the level of writing anxiety.

Regarding the types of EFL writing anxiety, first-year medical students experienced cognitive anxiety most, similar to the results of studies by Rezaei and Jafari, ${ }^{19}$ Cheng, ${ }^{34}$ Zhang, ${ }^{66}$ and Kurniasih. ${ }^{67}$ The outcome of the types of writing anxiety is precisely contrary to the studies previously carried out by Ekmekçi, ${ }^{5}$ and Wahyuni and $\mathrm{Umam}^{68}$.Their studies revealed that somatic anxiety was the major type of EFL writing anxiety faced by EFL learners. Their participants were unable to manage EFL writing anxiety, which affected their physiological symptoms such as tension and rapid heart rate.

Cognitive anxiety is a mental activity in the human brain, and it is related to the intellectual aspect of learners when they experience anxiety. ${ }^{34}$ As stated by Zhang, ${ }^{66}$ cognitive anxiety is connected with negative expectations of EFL learners; they are worried about tests and evaluation in English writing. When cognitive anxiety is the

Table 3 Contexts and Factors Causing Anxiety When Write in English

\begin{tabular}{|l|l|l|l|}
\hline & High Anxious Group & Moderate Anxious Group & Low Anxious Group \\
\hline Poor linguistic knowledge & 5 & 4 & 2 \\
Insufficient writing practice & 4 & 3 & 3 \\
Insufficient writing technique & 5 & 3 & 2 \\
Fear of writing tests & 5 & 3 & 2 \\
Fear of teacher's negative evaluation & 4 & 3 & 3 \\
Lack of interest in writing & 3 & 2 & 1 \\
Lack of sufficient time for writing practice & 4 & 3 & 2 \\
\hline
\end{tabular}


primary type of EFL writing anxiety of the participants, it signifies that they have difficulties concentrating on the assigned writing tasks because of their fear of test or worry of negative evaluation. They may even become worried when they overwhelm themselves to write composition free of linguistic errors. The statements of the respondents interviewed by the researchers reinforce this result. For instance, two interviewees stated the following:

I usually become stress about what to do when I have an assignment to write.

No matter what to do, I will be worried about my English teacher's comments.

This result implies that students experiencing cognitive anxiety must fight to lessen their anxiety level by learning to control their minds against negative factors that come from outside.

In terms of the main causes of EFL writing anxiety, the results of this study were linguistic difficulties, insufficient writing practice, low self-confidence in writing, and fear of writing tests. The finding of the study is consistent with the results reported by Zhang, ${ }^{66}$ and Wahyuni and Umam, ${ }^{68}$ they stated that the most obvious factor causing EFL writing anxiety was linguistic difficulties. Conversely, the result of this study is inconsistent with the results of Rezaei and Jafari's research indicated that the main causes of writing anxiety were fear of teachers' negative feedback, followed by low self-confidence, finally poor linguistic knowledge. $^{19}$

The results of the qualitative data obtained from the interview support the results obtained from the analysis of the CWA. The students reported the main factors causing writing anxiety were poor linguistic knowledge, insufficient writing practice, fear of writing tests, and negative evaluations by teachers. They added other two factors which were lack of sufficient time for writing practice, and lack of interest in writing.

Therefore, students with insufficient vocabulary, poor grammatical knowledge, and lack of writing practice often think a lot about the form of writing causing them to be anxious. These sources can be considered as signs of the presence of cognitive anxiety among the medical students.

\section{Conclusion}

Generally, many factors involved in EFL writing anxiety, as an underestimated factor in the Jordanian EFL context, were addressed in the present study. The value of the present study lies in the fact that as a novel study in the Jordanian EFL educational context. It inspects the levels, types, and causes of writing anxiety among first-year medical students in Jordan learning English as a foreign language, using a mixed-method design which validates the obtained results. The study showed high levels of EFL writing anxiety among first-year medical students, which were mainly cognitive, as reflected in poor linguistic knowledge, insufficient writing practice, low self-confidence, and fear of writing tests.

These problems are essential for education in Jordan which rouses fears such as that of the evaluation of teachers of the students' writings, pressure for perfect writing performance, and students being incompatible with their expectations. These findings propose that educational goals in Jordan should develop a clear understanding of the writing needs of EFL learners and help them to reduce their fear of being assessed according to their writing ability and language proficiency. It is essential to be aware of EFL students' burden of the writing process along with the fear of making mistakes because of their limited linguistic knowledge and ability to develop their ideas in English. Therefore, it is recommended that these shortcomings, which are mainly rooted in classroom practices, can be removed by applying a balanced assessment established on numerous measures as content, creativity, structure, and originality that might lessen students' anxiety caused by errors. Teachers can help students to alleviate anxiety by using studentteacher interaction that holds a significant contributing factor to cognitive anxiety arousal.

More studies are recommended on EFL writing anxiety to add useful information to the limited literature available on this issue in the Jordanian educational setting. The findings of the current study would be beneficial to other educational settings. Language teachers and syllabus designers have to be aware of the existence of EFL writing anxiety and need to offer help to reduce writing anxiety.

\section{Disclosure}

The authors report no conflicts of interest for this work.

\section{References}

1. Brown HD. Principles of Language Learning and Teaching. 5th ed ed. New York: Pearson; 2007.

2. Ali TT, Fei WF. Foreign language classroom anxiety among Iraqi students and its relation with gender and achievement. Int $J$ Appl Lingu Engl Lit. 2017;6(1):305-310. doi:10.7575/aiac.ijalel.v.6n.1p.305

3. Yassin AA, Razak NA. Investigating the relationship between foreign language anxiety in the four skills and year of study among Yemeni university EFL learners. Southeast Asian J Engl Lang Stud. 2015;3 (3):147-159. doi:10.17576/3L-2017-2303-11 
4. MacIntyre PD, Gardner RC. The subtle effects of language anxiety on cognitive processing in the second language. Lang Learn. 1994;44 (2):283-305

5. Ekmekçi E. Exploring Turkish EFL students' writing anxiety. Read Matrix Int Online J. 2018;18(1):158-175.

6. Horwitz EK, Horwitz MB, Cope J. Foreign language classroom anxiety. Modern Lang J. 1986;70(2):123-132.

7. Kara S. Writing anxiety: a case study on students' reasons for anxiety in writing classes. Anadolu J Edu Sci Int. 2013;3(January):103-111.

8. Kondo DS, Ling YY. Strategies for coping with language anxiety: the case of students of English in Japan. ELT Jl. 2004;58(3):258-265. doi:10.1093/elt/58.3.258.

9. Pappamihiel NE. English as a second language students and English language anxiety: issues in the mainstream classroom. Research Teach Engl. 2002;36(3):327-355. doi:10.2307/40171530.

10. Cheng Y-S. Factors associated with foreign language writing anxiety. Foreign Language Annals. 2002;35(6):647-656. doi:10.1111/j.19449720.2002.tb01903.x

11. Kurt G. Eğitimde Kuram ve Uygulama. Online Submiss. 2007;3 (1):12-23.

12. MacIntyre PD, Gardner RC. Anxiety and Second-Language Learning: toward a Theoretical Clarification. Lang Learn. 1989;39 (2):251-275. doi:10.1111/j.1467-1770.1989.tb00423.x

13. Daud NM. Second language writing anxiety: cause or effect? Malaysian J ELT. 2005;1-19.

14. Chamot AU. Language learning strategy instruction: current issues and research. Annual Review of Applied Linguistics. 2005;25:112-130. doi:10.1017/S0267190505000061.

15. Kırmız1 AÖ. An Investigation of L2 learners' writing self-efficacy, writing anxiety and its causes at higher education in Turkey. Int J High Educ. 2015;4(2). doi:10.5430/ijhe.v4n2p57

16. Ho M. Exploring Writing Anxiety and Self-Efficacy among EFL Graduate Students in Taiwan. Higher Education Studies. 2015;6 (1):24-39. doi:10.5539/hes.v6n1p24.

17. Shang H. Factors associated with English as a foreign language university student writing anxiety. Int J Engl Lang Teach. 2013;19 (1):35-44. doi:10.18848/2327-7955/CGP/v19i01/48701.

18. Salem AM, Foo TV. Mother tongue influence on writing apprehension of Jordanian student studying English language: case study. Int $J$ Engl Edu. 2013;2(1):46-51.

19. Rezaei M, Jafari M. Investigating the levels, types, and causes of writing anxiety among Iranian EFL students: A mixed method design. Procedia - Social and Behavioral Sciences. 2014;98:1545-1554. doi:10.1016/j.sbspro.2014.03.577

20. Sabti AA, Md Rashid S, Nimehchisalem V, Darmi R. The Impact of writing anxiety, writing achievement motivation, and writing self-efficacy on writing performance: A correlational study of Iraqi tertiary EFL Learners. SAGE Open. 2019;9(4):1-13. doi:10.1177/ 2158244019894289

21. Huwari I, Hashima N. Oral Communication Apprehension in English Among Jordanian Postgraduate Students in Universiti Utara Malaysia. In Proceedings of the 3rd International Conference on International Studies (ICIS). Kuala Lumpur, Malaysia; 2010.

22. Rabab'ah G. Communication problems facing Arab learners of English: A personal perspective. TEFL Web J. 2005;2(1):15-30.

23. Abdul Haq F. An Analysis of Syntactic Errors in the Composition of Jordanian Secondary Students. [Dissertation]. Irbid: University of Yarmouk; 1982.

24. Khuwaileh AA, Shoumali A AA. Writing errors: A study of the writing ability of arab learners of academic english and Arabic at university. Language, Culture and Curriculum. 2000;13(2):174-183. doi:10.1080/07908310008666597

25. AL-Khataybeh M. An Analysis of Syntactic Errors in the Composition of Jordanian Tenth Grade Students. [Dissertation]. Irbid: Yarmouk University-Jordan; 1992.
26. Zughoul M, Fayez Hussein R. English for higher education in the Arab world: A case study of needs analysis at Yarmouk University. The ESP Journal. 1985;4(2):133-152. doi:10.1016/0272-2380(85) 90016-2

27. Zughoul MR. Error in lexical choice: towards writing problematic World Lists. IRAL. 1991;29(1):45-60.

28. Hussein A, Mohammad M. Negative L1 impact on L2 writing. Int J Human Soci Sci. 2011;1(18):184-195.

29. Al Bataineh KB. English language learning beliefs of Jordanian students: the effect of gender. Int J Eng Ling. 2019;9(2):219-228.

30. Bani-Khaled TD. Learning English in difficult circumstances: the case of North Badiah disadvantaged schools in Jordan. Aust J Basic Appl Sci. 2013;7(8):269-284.

31. Wahba E. Teaching pronunciation-why? Lange Teach Forum. 1998;36:3-32.

32. Hassan BA. The relationship of writing apprehension and self-esteem to the writing quality and quantity of EFL University students. Mansoura Faculty Educ J. 2001;4:3-37.

33. Horwitz EK. Language anxiety and achievement. Ann Rev Appl Lingu. 2001;21:112-126.

34. Cheng YS. A measure of second language writing anxiety: scale development and preliminary validation. J Second Lang Writing. 2004;13(4):313-335. doi:10.1016/j.jslw.2004.07.001.

35. Daly JA, Miller MD. Apprehension of Writing as a Predictor of Message Intensity. J Psychol. 1975;89(2):175-177. doi:10.1080/ 00223980.1975 .9915748

36. Faigley L, Daly JA, Witte SP. The role of writing apprehension in w riting performance and competence. J Educ Res. 1981;75 (1):16-21. doi:10.1080/00220671.1981.10885348

37. Rose M. Writer's Block: The Cognitive Dimension. Southern Illinois: University Press; 1983.

38. Rankin-Brown M Addressing writing apprehension in adult English language learners. Proceedings of the CATESOL state Conference; 2006.

39. Onwuegbuzie AJ. Writing a research proposal: the role of library anxiety, statistics anxiety, and composition anxiety. Library Info Sci Res. 1997;19(1):5-33. doi:10.1016/S0740-8188(97)90003-7.

40. Huwari IF, Abd Aziz NH. Writing apprehension in English among Jordanian postgraduate students at Universiti UTARA Malaysia. Academic Res Int. 2011;1(2):190-198.

41. Al-Sawalha A, Foo C. The effects of writing apprehension in English on the writing process of Jordanian EFL students at Yarmouk University. Int Inter $J$ Edu. 2012;1(1):6-14.

42. Haddad MTA. Writing anxiety and the use of subordinate clauses in the written compositions of Jordanian EFL undergraduate students. Theory Practice Lang Stud. 2018;8(4):404-409.

43. Zhang X. Exploring the relationship between college students' writing anxiety and the pedagogical use of online resources. Int J Educ Technol High Educ. 2019;16(1):18. doi:10.1186/ s41239-019-0149-y

44. Aida Y. Examination of Horwitz, Horwitz, and Cope's construct of foreign language anxiety: the case of students of Japanese. Modern Lang J. 1994;78:155-168.

45. Ehrman ME. Understanding Second Language Learning Difficulties. London: Sage Publication, Inc; 1996.

46. Brown JD, Robson G, Rosenkjar PR. Personality, motivation, anxiety, strategies, and language proficiency of Japanese students. In: Dörnyei Z, Schmidt R, editors. Motivation and Second Language Acquisition. Honolulu: University of Hawaii; 2001:361-391.

47. Al-Saraj T. Foreign Language Anxiety: What is It? Paper Presented at 4th Bloomsbury Student Conference in Applied Linguistics. Birkbeck: University of London; 2011.

48. Spielmann G, Radnofsky ML. Learning language under tension: new directions from a qualitative study. Modern Lang J. 2001;85 (2):259-278. 
49. Horwit EK. Preliminary evidence for the reliability and validity of a foreign-language anxiety scale. Tesol Quart. 2001;20(3):559-562. doi: $10.2307 / 3586302$

50. Kitano K. Anxiety in the college Japanese language classroom. Modern Lang J. 2001;85:549-566.

51. Jebreil N, Azizifar A, Gowhary H, Jamalinesari AA. Study on Writing Anxiety among Iranian EFL Students. Int J Appl Lingu Engl Lit. 2015;4:2. doi:10.7575/aiac.ijalel.v.4n.2p.68

52. Frantzen D, Magnan SS. Anxiety and the true beginner-false beginner dynamic in beginning French and Spanish classes. Foreign Lang Ann. 2005;38(2):171-186. doi:10.1111/j.1944-9720

53. Shahnaz A, Bhatti KK. An analysis of relationship between English language anxiety, English Language interest and English Language achievement. Int J Engl Edu. 2014;3(1):175-186.

54. Cheng Y-S, Horwitz EK, Schallert DL. Language anxiety: differentiating writing and speaking components. Lang Learn. 1999;49:417-446.

55. Argaman O, Abu-Rabia S. The influence of language anxiety on English reading and writing tasks among native Hebrew speakers. Lang Cult Curric. 2002;15:143-160.

56. Al-Shboul MM, Ahmad IS, Nordin MS, Rahman ZA. Foreign language anxiety and achievement: systematic review. Int J Engl Lingu. 2013;3(2):32-45. doi:10.5539/ijel.v3n2p32

57. Park H, Lee AR. L2 learners' anxiety, self-confidence and oral performance. Proceedings of 10th Conference of Pan-Pacific Association of Applied Linguistics; 2005; Edinburgh University, 197-208.

58. Golchi MM. Listening anxiety and its relationship with listening strategy use and listening comprehension among Iranian IELTS learners. Int J Engl Lingu. 2012;2:4. doi:10.5539/ijel.v2n4p115
59. Huerta M, Goodson P, Beigi M, Chlup D. Graduate students as academic writers: writing anxiety, self-efficacy and emotional intelligence. High Educ Res Dev. 2017;36(4):716-729. doi:10.1080/ 07294360.2016 .1238881

60. Sellers VD. Anxiety and reading comprehension in Spanish as a foreign language. Foreign Lang Ann. 2000;33(5):512-520.

61. Erkan YD, Saban AI. Writing performance relative to writing apprehension, self-efficacy in writing, and attitudes towards writing: A correlational study in Turkish tertiary-level EFL. Asian EFL J Quart. 2011;13(1):163-191.

62. Al-Shboul Y, Huwari IF. The causes of writing apprehension through students' perspective. J Lang Teach Res. 2015;6(3):535-544. doi: $10.17507 / j$ ltr.0603.08.

63. Liu M. Anxiety in Chinese EFL students at different proficiency levels. System. 2006;34(3):301-316. doi:10.1016/j.system.2006.04.004.

64. Lee SY. The influence of cognitive/affective factors on literacy transfer. Stud Engl Lang Lit. 2002;8(10):17-32.

65. Syarifudin S. Survey on EFL students' writing anxiety: level, types, and causes. Eralingua. 2020;4(2):122-132.

66. Zhang H. A Study on ESL Writing Anxiety Among Chinese English Major-Causes, Effects and Coping Strategies for ESL Writing Anxiety [Dissertation]. Kristiansan: University of Sweden; 2011.

67. Kurniasih K. Writing anxiety in relation to high performing students' English compositions. J Engl Lang Teach. 2017;1(1):1-8.

68. Wahyuni S, Umam MK. An analysis on writing anxiety of Indonesian EFL college learners. J Engl Educ Lingu Stud. 2019;4 (1):103-126.
Psychology Research and Behavior Management

\section{Publish your work in this journal}

Psychology Research and Behavior Management is an international, peer-reviewed, open access journal focusing on the science of psychology and its application in behavior management to develop improved outcomes in the clinical, educational, sports and business arenas. Specific topics covered in the journal include: Neuroscience, memory and decision making; Behavior modification and management; Clinical

\section{Dovepress}

applications; Business and sports performance management; Social and developmental studies; Animal studies. The manuscript management system is completely online and includes a very quick and fair peer-review system, which is all easy to use. Visit http://www. dovepress.com/testimonials.php to read real quotes from published authors. 